\title{
Older International \\ Migrants: who migrates to England and Wales in later life?
}

\author{
Marcus Green, Maria Evandrou and \\ Jane Falkingham \\ Centre for Research on Ageing \\ and ESRC Centre for Population \\ Change, University of Southampton
}

\section{Introduction}

Between 1 April 2000 and 1 April 2001 in England and Wales, over 430,000 persons of the age of 60 and over migrated at some level, either internally within England and Wales, within the UK or transnationally (Office for National Statistics, 200111). As a segment of the 60 and over population as a whole, this makes up just 4 per cent. The percentage of migrants among the total population across all ages is higher at 11.5 per cent.

In the year prior to the 2001 Census, approximately 10,500 persons migrated to England and Wales from outside the UK at ages 60 and over (Office for National Statistics, 2001 ${ }^{11}$ ). This demographic flow accounts for 2.4 per cent of all migrant activity among those aged 60 and over which may explain the lack of research undertaken in this area. However, with data from future censuses and the ONS Longitudinal Survey it will not only be possible to investigate whether the number of persons migrating to England and Wales in retirement is increasing, but also to find out more about the characteristics of these individuals.

This article explores the demographic characteristics of these older international migrants and contrasts their profiles against those of the total resident population of the same age. This enables identification of crucial differences that may explain their varying migratory outcomes. The article focuses on characteristics such as ethnicity, marital status, housing tenure and health.

There is increasing demand for services geared towards maintaining health and other aspects of quality of life at older ages. It is important to understand how these services might need to adapt to a growing and increasingly diverse older population. Understanding how these
Over the past half century, two major demographic phenomena have risen to prominence: population ageing and international migration (United Nations, 2005). ${ }^{1}$ It has recently been estimated that there are over 200 million international migrants in the world (International Organization for Migration, 2008). ${ }^{2}$ This comprises around 3 per cent of the current world population (U.S Census Bureau, 2008). ${ }^{3}$ The increasingly mobile global population is also ageing. In 2006 , the UN estimated that 11 per cent of the world's population was aged 60 and over (United Nations, 2006); 4 in the UK those aged 60 and over accounted for 21 per cent of the total population (Office for National Statistics, 2006). ${ }^{5}$ Previous UK research on migration in later life has primarily focused on international migration from England and Wales to foreign destinations in retirement (Williams et al, 1997; King et al, 1998; ${ }^{7}$ Warnes and Guy, $1998 ;{ }^{8}$ King et al, 2000; ${ }^{9}$ Casado-Diaz et al, $2004^{10}$ ) and there has been little research on migration to the UK at older ages. This article contributes to the latter literature by beginning to create a profile of those individuals who migrate to England and Wales from outside the UK at retirement age. 
requirements may vary is therefore critical for policy makers and planners.

\section{Background, data and methodology}

The literature on international migration tends to emphasise the dynamics of work and economic factors and rarely takes a life course approach, one where an individual's educational and cultural upbringing and previous experience of migration are also considered as important in the decision-making process. However studies of migration in later life have revealed that migration decisions are the result of a complex set of interactions between social conditions, environmental conditions and personal circumstances (Rodgers et al, $1992^{12}$ ). The types of move vary according to stage of the life course and the associated life events. For example, long-distance residential moves may be undertaken around time of retirement. Such moves often involve a change of place of residence and a move to a more 'desirable' place, moving out of uan area to a rural area or to the coast. These moves may be seen as amenity driven i.e. to improve the quality of life. In contrast, short-distance moves may occur at older ages when people perhaps move from a house into a flat to help them remain living independently in the community. Demographic changes may also precipitate a move. For example, the death of a spouse may prompt a move to be closer to adult children as might the birth of a grandchild, with grandparents providing care and facilitating their adult children to participate in the labour market. Thus moves may be 'amenity' driven, i.e. where the move is undertaken to better the migrants' quality of life, but may also be precipitated by the need to care or the need for care. Ackers and Dwyer $\left(2002^{13}\right)$ argue that migration in later life should therefore be seen as a process in constant flux. The close link between life course events and the progressive unfolding of the care relationship means that in practice people are involved in a series of migration decisions and re-evaluation of those decisions. Migration decisions that involve a move across international borders may involve more evaluation than most.

As mentioned in the introduction, to date very little attention has been given to international retirement migration to England and Wales. Studies on international migration have tended to focus on immigration to the

\section{Box one}

\section{Definitions}

- Internal migrants/migration - a change of residence within England and Wales.

- International migrants/migration - individuals who have migrated to England and Wales from outside the UK.

- Retired/retirement - an individual aged 60 and over migrating to England and Wales (with intent to stay long-term) is assumed to be economically inactive, given the UK's admittance criteria at these ages (UK Borders Agency, 2008 ${ }^{14}$ ).

- Older-old - those aged 80 and over.

- Younger-old - those aged between 60 and 79 .

- International retirement migration - an individual who changes their country of usual residence for at least a year, while in retirement, so that the country of destination becomes the country of usual residence (Office for National Statistics, 2008 ${ }^{15}$ ).

- Return retirement migration - a migration whereby the mover returns to their place of origin after the initial retirement move within retirement.

- Amenity migration - a migration where one moves to better the quality of life.
UK and consequent policies concerning the migrations of those seeking work, family reunification, asylum seekers and refugees. On the other hand, when retirement migration is discussed, it is the outward flow of British citizens to 'sunset' destinations that receives the most research and media interest. In that sense, this article presents the other side of the story, the rather under-researched occurrence of migrants coming to England and Wales in later life in retirement.

It is important to consider the social, economic and political context that surrounds these retirement migrants. The admission requirements are fairly stringent in the criteria they demand prior to approving entry to England and Wales. According to the UK Borders Agency (UK Borders Agency, 2008 ${ }^{14}$ ) entry criteria are based on one's financial circumstance, social connections to the UK and independence from employment. A retired migrant needs to evidence a disposable income of $£ 25,000$ per annum, prove to have relatives in the UK and the ability to maintain themselves without the assistance of public funds as well as committing to not undertaking any form of employment. Entry to the UK is granted for an initial five year period, which will require extension upon expiry if the individual intends to secure an 'indefinite leave to remain.'

The number of people coming to the UK was recorded in the 2001 Census. Recent international migrants were identified using answers provided by the 'address one year ago' question. The census provides a rich and vast range of demographic variables for people and households, the only drawback of the census is its infrequency. The 2001 Census data allow us to investigate how migratory outcomes vary by inherent characteristics such as age, gender and ethnicity and life course characteristics such as health, marital statutes and housing tenures.

All of the data analysed in this study are derived from the 2001 Census Data tables including age, gender, ethnicity, health, marital status and housing tenure of older migrants and non-migrants between April 2000 and April 2001 within England and Wales by migration type were provided by the Office for National Statistics. The data provided are anonymous and unrounded. In order to arrange the data to allow for comparison, contingency tables were created with values expressed as percentages in addition to absolute numbers. Each contingency table was tested for statistical significance using Chi square in order to provide evidence of the variation in demographic characteristics by migration status.

The 2001 Census offers the most complete coverage of migratory behaviour in England and Wales for the period 2000-2001. The response rate for the 2001 Census was 94 per cent (Office for National Statistics, $2006^{5}$ ), and although not as high as in previous censuses, still provides a good representation of the demographic profiles of migrants and nonmigrants in England and Wales. Not only is its coverage appropriate for such a study, it provides a wide-range of socio-economic and intrinsic variables that give a full story as to who these migrants are that in turn aids a better understanding as to why perhaps they choose to migrate internationally to England and Wales in later life. Furthermore, having access to the same demographic characteristics for non-migrants enables fruitful comparison.

Other sources of migration statistics such as the International Passenger Survey (IPS) ${ }^{16}$ were not sufficiently robust to be considered as a main data provider for this study. The IPS has a sample size that represents around 1 in 500 passengers (approximately 250,000 annual travellers). This is not sufficient to provide reliable estimates of rare events such as international retirement migration (to England and Wales). Estimates of international in-flow migration for males and females of State Pensionable Age (SPA) from the IPS have standard errors greater than 25 per cent and are therefore not considered reliable. 
Men and women at all ages by migration status, England and Wales 2001

\begin{tabular}{|c|c|c|c|}
\hline & $\begin{array}{l}\text { Men aged } 60 \\
\text { and over }\end{array}$ & $\begin{array}{l}\text { Women aged } 60 \\
\text { and over }\end{array}$ & All \\
\hline $\begin{array}{l}\text { Internal migrants } \\
\text { (moved address within England and Wales } \\
\text { in last year) }\end{array}$ & 170,700 & 250,100 & $5,492,500$ \\
\hline $\begin{array}{l}\text { Internal 'International' migrants } \\
\text { (moved into E and W from an address } \\
\text { elsewhere within the UK in last year) }\end{array}$ & 1,100 & 1,500 & 55,000 \\
\hline $\begin{array}{l}\text { International migrants } \\
\text { (moved into } E \text { and } W \text { from an address } \\
\text { outside the UK in last year) }\end{array}$ & 5,200 & 5,400 & 370,400 \\
\hline Non-migrants & $4,551,900$ & $5,839,400$ & $45,703,900$ \\
\hline Total number & $4,728,900$ & $6,096,400$ & $51,621,800$ \\
\hline
\end{tabular}

Source: 2001 Census

\section{Migration and mobility in later life}

Around 1 in 10 people in the UK had moved address in the year prior to the Census in April 2001. Migration at ages 60 and over is, however, less common with around 0.4 in every 10 changing address in the previous year. The most prominent form of migration among those aged 60 and over are moves within England and Wales, with a higher ratio of older women experiencing such a move than older men (4.1 in 100 persons compared with 3.6 in 100 persons). International migration to England and Wales occurs at a significantly lesser scale; just 0.1 in 100 persons aged 60 and over present in England and Wales at the time of the Census in 2001 had moved from an address outside the UK in the previous year compared with 0.7 in 100 persons for the population of all ages. With the number of annual international migrants to England and Wales determined (Table 1), the characteristics of people who migrate to England and Wales from outside the UK are now explored.

\section{Age at migration}

Table 2 shows the age distribution of older international migrants as compared with that of the total population aged 60 and over resident in England and Wales in 2001. International migrants tend to be younger, with those aged 60-69 comprising 62 per cent of migrants compared to just 45 per cent of the older population as a whole. This could say something about the motives of these migrants. Individuals are more likely to be healthier and therefore more mobile at younger ages. Conceivably as this move could be occurring at the point of an individual's retirement, the migration may be undertaken on the basis of 'amenity', in other words to better one's quality of life. This migratory motive contrasts with late-life migrations which are often dictated by issues concerning health. Another reason for migration at this stage of the life course could be family reunification. It is often the case that foreign-born workers in England and Wales are joined by older relatives such as parents and grandparents once they themselves have been employed for a satisfactory period of time in England and Wales, hold the

\section{Table 2}

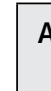

\begin{tabular}{l|c|c}
\hline Age group & $\begin{array}{c}\text { International migrants to E and W } \\
\text { aged } 60 \text { and over }\end{array}$ & $\begin{array}{c}\text { All people resident in E and W } \\
\text { aged } 60 \text { and over }\end{array}$ \\
\hline $60-69$ & $6,508(61.8 \%)$ & $4,837,235(44.7 \%)$ \\
$70-79$ & $2,759(26.2 \%)$ & $3,829,577(35.4 \%)$ \\
$80-89$ & $1,093(10.4 \%)$ & $1,855,000(17.1 \%)$ \\
$90+$ & $174(1.7 \%)$ & $335,713(3.1 \%)$ \\
Total (N) & $10,534(100 \%)$ & $10,830,525(100 \%)$ \\
\hline
\end{tabular}

\section{Figure 1} the 1 Gender composition of all older international migrants, England and Wales, 2001

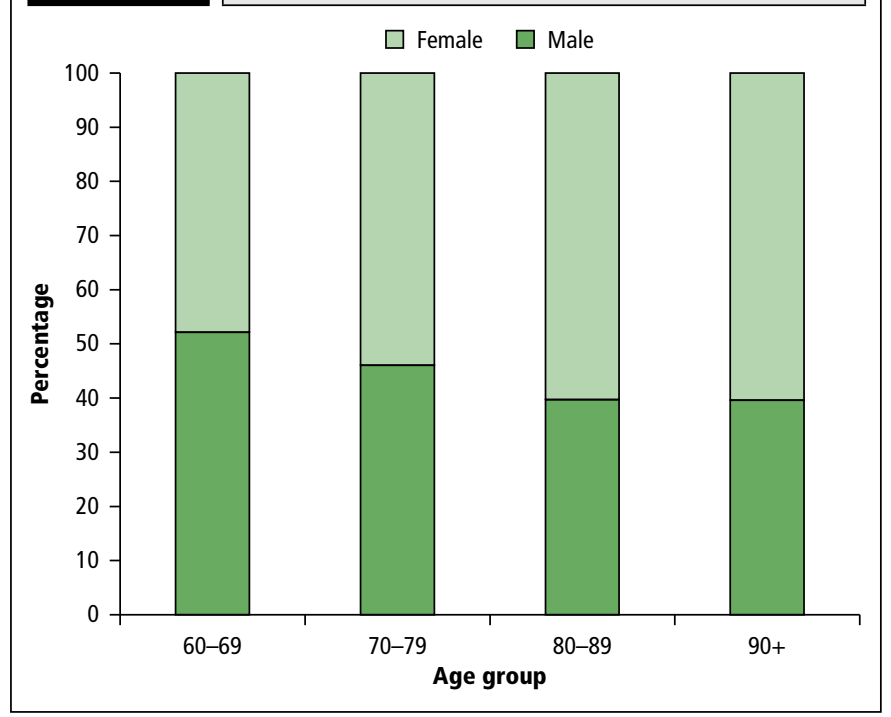

Source: 2001 Census

relevant 'points based system' migrant ranking or share familial networks with UK citizens (Castles and Miller, 2003 ${ }^{17}$ ).

Further disaggregation of older migrants within age groups by gender highlights some interesting differences. As can be seen from Figure 1, females make up a disproportionate share of international migrants, and their share rises with age; 48 per cent of those aged 60-69 are female compared with 60 per cent of those aged 80 and over. At first sight this is surprising as previous studies have found that men are more likely to migrate than women. However, it is important to bear in mind that later life is highly gendered, with women generally enjoying a higher life expectancy than men (Office for National Statistics, $2008^{18}$ a). Comparing the percentage share of men among migrants with the share of men in the total resident population within age groups (Figure 2), it is clear that international migrants are actually more likely to be male than the older population as a whole. This is especially the case at ages 90 and over, where 40 per cent of international migrants are male compared with just 23 per cent of the total resident population.

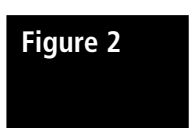

Percentage male among older international migrants and all older residents, England and Wales, 2001

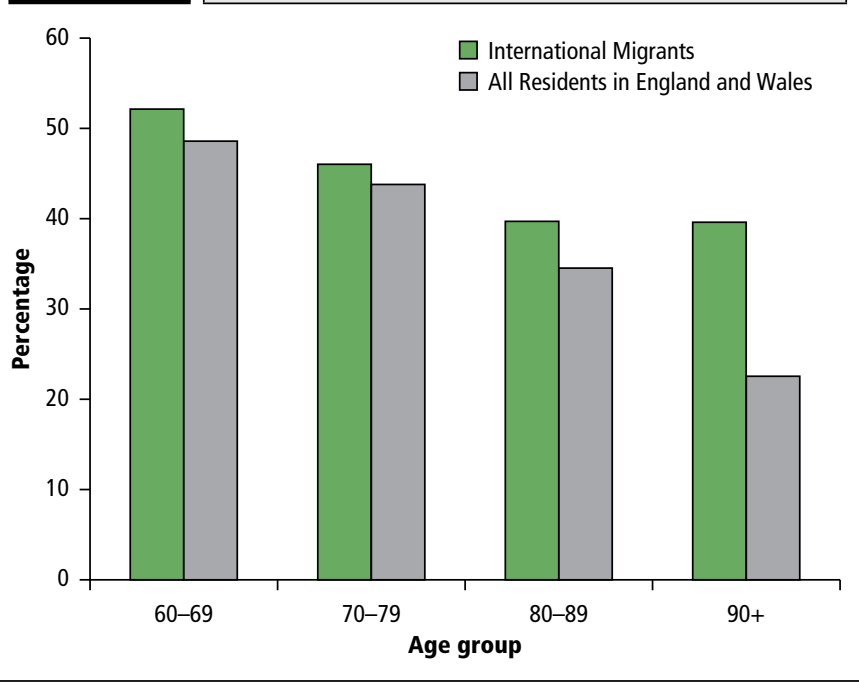

Source: 2001 Census 
Ethnicity of older international migrants (outside the UK) against the population by age

\begin{tabular}{l|r|r|r}
\hline Ethnicity & $\begin{array}{r}\text { International migrants } \\
\text { to E and W } \\
\text { aged } 60 \text { and over }\end{array}$ & $\begin{array}{r}\text { Internal migrants } \\
\text { to E and W } \\
\text { aged } 60 \text { and over }\end{array}$ & $\begin{array}{c}\text { All people resident } \\
\text { in E and W } \\
\text { aged } 60 \text { and over }\end{array}$ \\
\hline White & $8,220(78.0 \%)$ & $404,797(96.2 \%)$ & $10,497,143(96.7 \%)$ \\
Mixed & $162(1.5 \%)$ & $1,383(0.3 \%)$ & $27,180(0.3 \%)$ \\
Asian or Asian British & $1,191(11.3 \%)$ & $7,965(1.9 \%)$ & $183,040(1.7 \%)$ \\
Black or Black British & $585(5.6 \%)$ & $5,147(1.2 \%)$ & $115,317(1.1 \%)$ \\
Chinese or other & $376(3.6 \%)$ & $1,435(0.3 \%)$ & $28,434(0.3 \%)$ \\
ethnic group & $10,534(100 \%)$ & $420,727(100 \%)$ & $10,851,114(100 \%)$ \\
Total (N) & & &
\end{tabular}

Source: 2001 Census

\section{Ethnicity}

The ethnicity of incoming international migrants in retirement is of potential interest to a wide audience including local and national government and the health sector. An awareness of an individual's ethnicity is important when considering cultural assimilation, health requirements, housing and public service needs. Older people from white ethnic groups account for over three-quarters of international moves to England and Wales at ages 60 and over (Table 3). This could suggest the return migration of expatriates who had worked abroad and are retiring in England and Wales or of older people who retired to southern Spain and other areas and are now returning at a later stage in their retirement. However over a fifth of moves are by non-white older people, around half of which are from south Asia (primarily Pakistan, India and Bangladesh) and a quarter are Black African or Black Caribbean. These moves at ages 60 and over are less likely to be economically motivated than among younger cohorts and could reflect moves for family reunification, where older relatives are rejoining their families.

There is little variation in the ethnic distribution of persons between those who migrated internally and the total resident population in England and Wales. It is the ethnic variation between international migrants and the total resident population that is of greater interest. For example, older people of south Asian ethnicity account for 11.3 per cent of all international older migrants but comprise just 1.7 per cent of the total resident population aged 60 and over living in England and Wales in 2001. Services aimed at recent older migrants may therefore need to be different from those for the general population.

Table 2 shows that the age distribution of incoming international migrants at age 60 and over is younger than for the total resident population in England and Wales. Table 4 shows that older international migrants of White ethnicity are more likely to migrate to England and ethnic group

\begin{tabular}{l|r|r|r|r|r}
\hline $\begin{array}{l}\text { Age } \\
\text { group }\end{array}$ & White & Mixed & \multicolumn{1}{c}{$\begin{array}{c}\text { Asian/Asian } \\
\text { British }\end{array}$} & \multicolumn{1}{c}{$\begin{array}{c}\text { Black/Black } \\
\text { British }\end{array}$} & $\begin{array}{c}\text { Chinese or } \\
\text { other ethnic } \\
\text { group }\end{array}$ \\
\hline $60-69$ & $5,167(62.9 \%)$ & $99(61.1 \%)$ & $668(56.1 \%)$ & $365(62.4 \%)$ & $209(55.6 \%)$ \\
$70-79$ & $2,079(25.3 \%)$ & $34(21.0 \%)$ & $380(31.9 \%)$ & $162(27.7 \%)$ & $104(27.7 \%)$ \\
$80+$ & $974(11.8 \%)$ & $29(17.9 \%)$ & $143(12.0 \%)$ & $58(9.9 \%)$ & $63(16.8 \%)$ \\
Total & $8,220(100 \%)$ & $162(100 \%)$ & $1,191(100 \%)$ & $585(100 \%)$ & $376(100 \%)$
\end{tabular}

Source: 2001 Census

Wales at a younger age than those of South Asian, Chinese or other ethnicity, adding weight to the suggestion that these individuals are returning from employment outside of the UK, potentially migrating at the point of retirement. Those of Mixed, Chinese or other ethnicities are more likely to immigrate to England and Wales at older-old ages (80+) than those of other ethnicities. Without further research it is difficult to determine the motivations leading to these migratory patterns. It might be that international migrants of the Mixed, Chinese or other ethnic group tend to reunite with their families at a later age than White, Black or Asian international migrants. Alternatively they could be making much later decisions in retirement, perhaps with more financial stability to fund a move to England or Wales, a migration they perceive to be amenitydriven. Some further light may be shed on the motives for moving internationally at older ages by looking at marital status.

\section{Legal marital status}

The percentage of older international migrants who are widowed or single increases with age while the number who are married declines with age (Table 5). Figure 3 illustrates differences in marital status among older international migrants as compared to all older people resident in England and Wales. A higher percentage of all residents are married ( 49.3 per cent) than is the case for migrants ( 44.8 per cent). This is perhaps expected as the effect of marriage upon migratory behaviour can be inhibiting. Whether or not both individuals within a marriage migrate, the concerns of two people need to be considered thus slowing down the process and consequently lessening the probability of a migration. The feeling of place attachment (from the place of origin) that two people may experience when contemplating an international migration in later life is greater than for one person. Similarly, a married couple are more likely to have offspring who may depend on them (and perhaps be adversely affected by their migration) and there are twice as many adult parents who may be dependent upon familial support. The finding that retirement migration rates are lower among married persons is well supported in migration studies literature (Warnes and Rees (1986); ${ }^{19}$ Speare and Goldsheider $(1987)^{20}$ and Bures $\left.(1997)^{21}\right)$. To be outside

\section{Table 5} Legal marital status of older international migrants by age

\begin{tabular}{|c|c|c|c|c|c|c|}
\hline \multirow[t]{2}{*}{ Marital status } & \multicolumn{5}{|c|}{ International migrants to England and Wales aged 60 and over } & \multirow{2}{*}{$\begin{array}{l}\text { All older people aged } 60 \\
\text { and over resident } \\
\text { in England and Wales }\end{array}$} \\
\hline & $60-69$ & $70-79$ & $80-89$ & $90+$ & $\begin{array}{c}\text { All ages } \\
\text { (60 and over) }\end{array}$ & \\
\hline Single & $424(6.5 \%)$ & $276(10.0 \%)$ & $182(16.7 \%)$ & $48(27.4 \%)$ & $930(8.8 \%)$ & $728,686(6.7 \%)$ \\
\hline Married & $3,354(51.5 \%)$ & $1,038(37.7 \%)$ & $292(26.8 \%)$ & $32(18.3 \%)$ & $4,716(44.8 \%)$ & $5,366,072(49.3 \%)$ \\
\hline Re-married & $1,004(15.4 \%)$ & $306(11.1 \%)$ & $62(5.7 \%)$ & $3(1.7 \%)$ & $1,375(13.1 \%)$ & $847,655(7.8 \%)$ \\
\hline Separated (but still legally married) & $274(4.2 \%)$ & $73(2.7 \%)$ & $12(1.1 \%)$ & $0(0.0 \%)$ & $359(3.4 \%)$ & $118,448(1.1 \%)$ \\
\hline Divorced & $666(10.2 \%)$ & $190(6.9 \%)$ & $45(4.1 \%)$ & $10(5.7 \%)$ & $911(8.7 \%)$ & $709,003(6.5 \%)$ \\
\hline Widowed & $785(12.1 \%)$ & $871(31.6 \%)$ & $495(45.5 \%)$ & $82(46.9 \%)$ & $2,233(21.2 \%)$ & $3,117,656(28.6 \%)$ \\
\hline Total (N) & $6,507(100 \%)$ & $2,754(100 \%)$ & $1,088(100 \%)$ & $175(100 \%)$ & $10,524(100 \%)$ & $10,887,520(100 \%)$ \\
\hline
\end{tabular}

Source: 2001 Census 


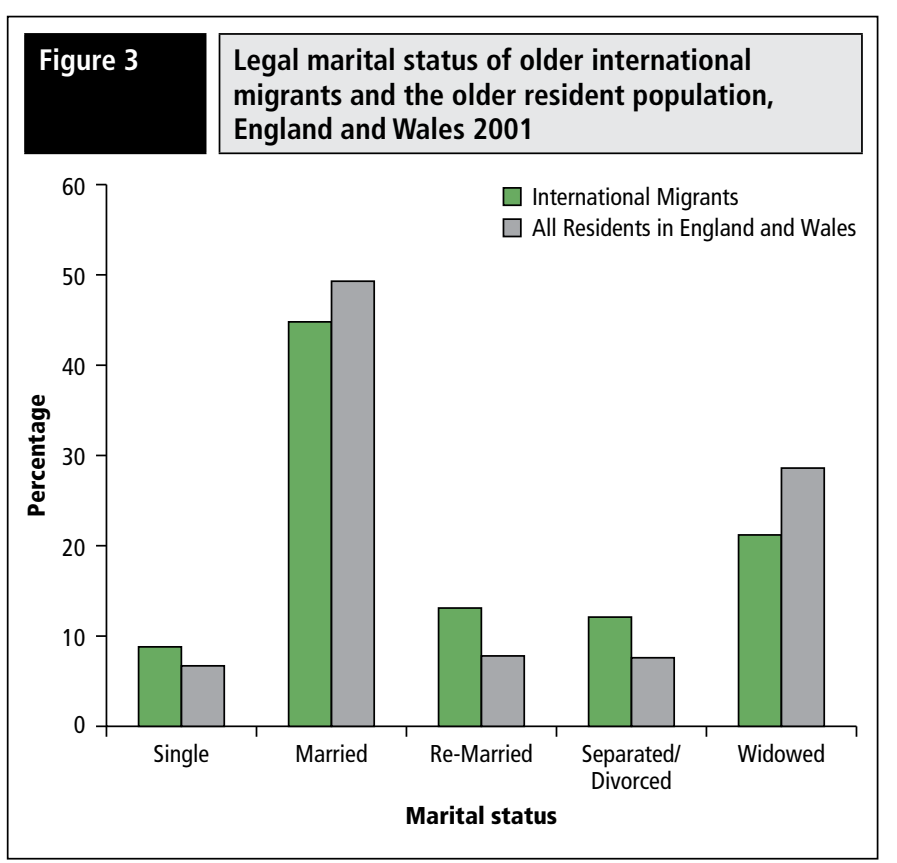

Source: 2001 Census

a form of union removes the 'anchor' and increases the potential for mobility in later life. Older international migrants are significantly more likely to be re-married (13 per cent) than is the case among the resident population ( 7.8 per cent). It may be that being in a second (or subsequent) marriage also reduces the number of ties to the country of origin.

Just over eight per cent more of the resident population are widowed than among international migrants ( 28.6 per cent versus 20 per cent), reflecting their older age structure.

Figure 4 presents data on the marital status of older international migrants by ethnic group. Across and within all ethnic groups, over half of older international migrants were married. This is the most common marital status regardless of ethnic group. Most variation is seen in the percentage of widowed across the ethnic groups, with around 37 per cent of Asian older international migrants to England and Wales between 2000 and 2001 being widowed, approximately six per cent more than

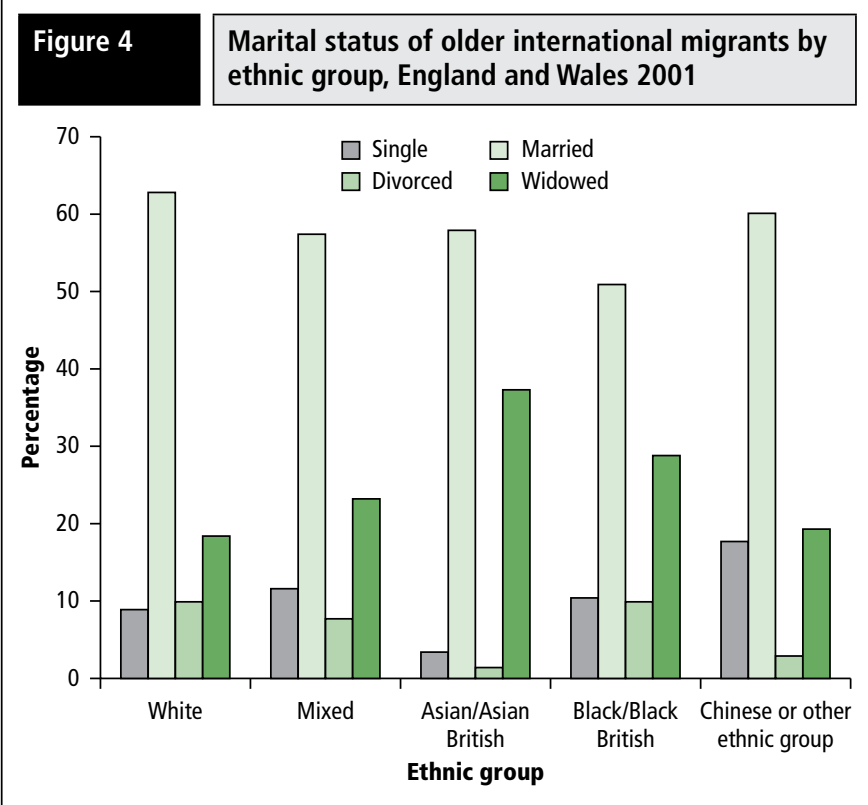

Source: 2001 Census

\section{Figure 5} Housing tenure of older international migrants and older residents, England and Wales 2001

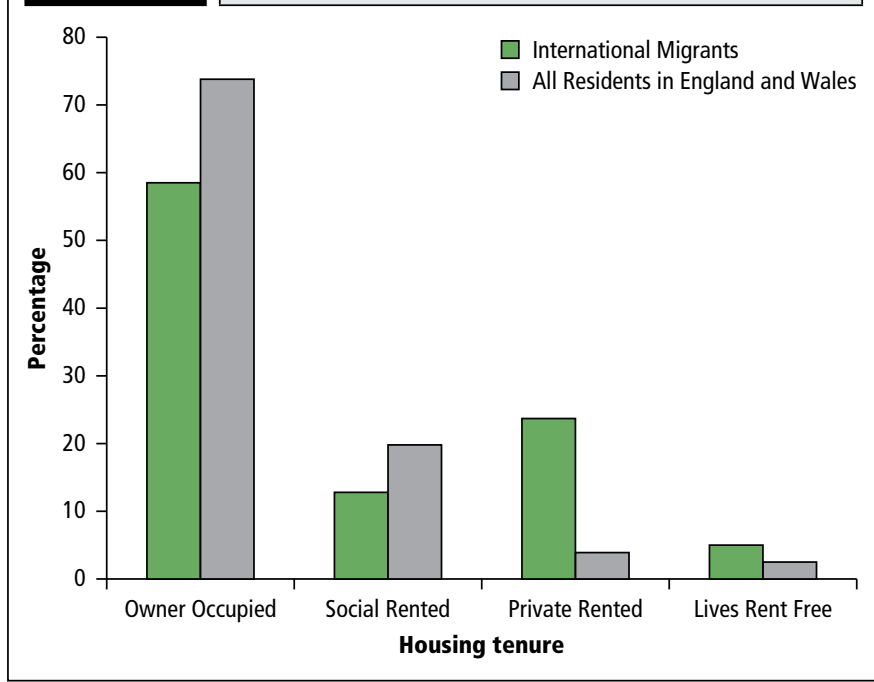

Source: 2001 Census

in any other ethnic group. In the same ethnic group, only 1.4 per cent of older international migrants were divorced. Again this suggests that older migrants of South Asian origin were coming to join younger family members.

\section{The socio-economic statuses of older international migrants}

Housing tenure is often used as a proxy indicator of socio-economic status. As Figure 5 illustrates, there is a distinct pattern of housing tenure depending on migration status. International migrants aged 60 and over were far more likely to live in private rented accommodation at the time of the 2001 Census ( 23.7 per cent) than all older residents ( 4.0 per cent). In contrast a substantially larger percentage of all residents own property outright ( 73.8 per cent) than international migrants ( 58.5 per cent). Only 12.8 per cent of older international migrants lived in social rented accommodation compared with 19.8 per cent of all those aged 60 plus in England and Wales. This could reflect a lack of access to this sector for recent migrants.

There is little difference in housing tenure by age among older migrants (Table 6). A higher proportion of those aged 90 and over live 'rent free' compared to other age groups, suggesting they may be dependant on accommodation financed by younger family members, although low cell counts make comparisons difficult.

Over 40 per cent of older international migrants to England and Wales between 2000 and 2001 from Black or Black British ethnic origin lived in social rented accommodation (Table 7 and Figure 6). This percentage is over three times greater than in the other ethnic groups. Conversely, only just over a third of older Black international migrants were owner occupiers, while within the other ethnic groups (White, Mixed, Asian or Asian British and Chinese or other ethnic group), over half of older international migrants were owner occupiers. Among older migrants of Chinese or other ethnic origin, almost a third lived in private rented accommodation; this is around seven per cent more than is evident among White older migrants. The percentages living rent free varies little across the ethnic groups.

\section{Health and migration in later life}

The 2001 Census includes a question on self-reported health status over the past year. Respondents could answer 'good', 'fairly good' 


\begin{tabular}{l|r|r|r|r|r|}
\hline Housing tenure & \multicolumn{5}{c|}{$\begin{array}{c}\text { All older people aged 60 and over } \\
\text { resident in England and Wales }\end{array}$} \\
\cline { 2 - 6 } & \multicolumn{1}{|c|}{$60-69$} & \multicolumn{1}{c|}{$70-79$} & $80-89$ & \multicolumn{1}{c}{$90+$} & All ages (60 and over) \\
\hline Owner occupied & $3,790(60.0 \%)$ & $1,500(57.3 \%)$ & $483(51.8 \%)$ & $68(59.7 \%)$ & $5,841(58.5 \%)$ \\
Social rented & $695(11.0 \%)$ & $428(16.4 \%)$ & $141(15.1 \%)$ & $11(9.7 \%)$ & $1,275(12.8 \%)$ \\
Private rented & $1,540(24.4 \%)$ & $563(21.5 \%)$ & $238(25.5 \%)$ & $24(21.1 \%)$ & $2,365(23.7 \%)$ \\
Lives rent free & $288(4.6 \%)$ & $127(4.9 \%)$ & $71(7.6 \%)$ & $11(9.7 \%)$ & $497(5.0 \%)$ \\
Total & $6,313(100 \%)$ & $2,618(100 \%)$ & $933(100 \%)$ & $114(100 \%)$ & $9,978(100 \%)$ \\
\hline
\end{tabular}

Source: 2001 Census

Table 7 Housing tenure of older international migrants by ethnicity

\begin{tabular}{|c|c|c|c|c|c|c|}
\hline \multirow[t]{2}{*}{ Housing tenure } & \multicolumn{5}{|c|}{ International migrants to England and Wales aged 60 and over } & \multirow{2}{*}{$\begin{array}{l}\text { All older people aged } 60 \text { and over } \\
\text { resident in England and Wales }\end{array}$} \\
\hline & White & Mixed & Asian/Asian British & Black/Black British & $\begin{array}{l}\text { Chinese or other } \\
\text { ethnic group }\end{array}$ & \\
\hline Owner occupied & $4,652(60.3 \%)$ & $80(54.4 \%)$ & $702(60.0 \%)$ & $200(35.8 \%)$ & $181(53.7 \%)$ & $7,721,495(73.8 \%)$ \\
\hline Social rented & $858(11.1 \%)$ & $19(12.9 \%)$ & $129(11.0 \%)$ & $231(41.4 \%)$ & $30(8.9 \%)$ & $2,070,749(19.8 \%)$ \\
\hline Private rented & $1,829(23.7 \%)$ & $40(27.2 \%)$ & $276(23.6 \%)$ & $101(18.1 \%)$ & $104(30.9 \%)$ & $419,935(4.0 \%)$ \\
\hline Lives rent free & $376(4.9 \%)$ & $8(5.5 \%)$ & $63(5.4 \%)$ & $26(4.7 \%)$ & $22(6.5 \%)$ & $256,986(2.5 \%)$ \\
\hline Total (N) & $7,715(100 \%)$ & $147(100 \%)$ & $1,170(100 \%)$ & $558(100 \%)$ & $337(100 \%)$ & $100 \%$ \\
\hline
\end{tabular}

Source: 2001 Census

\section{Figure 6}
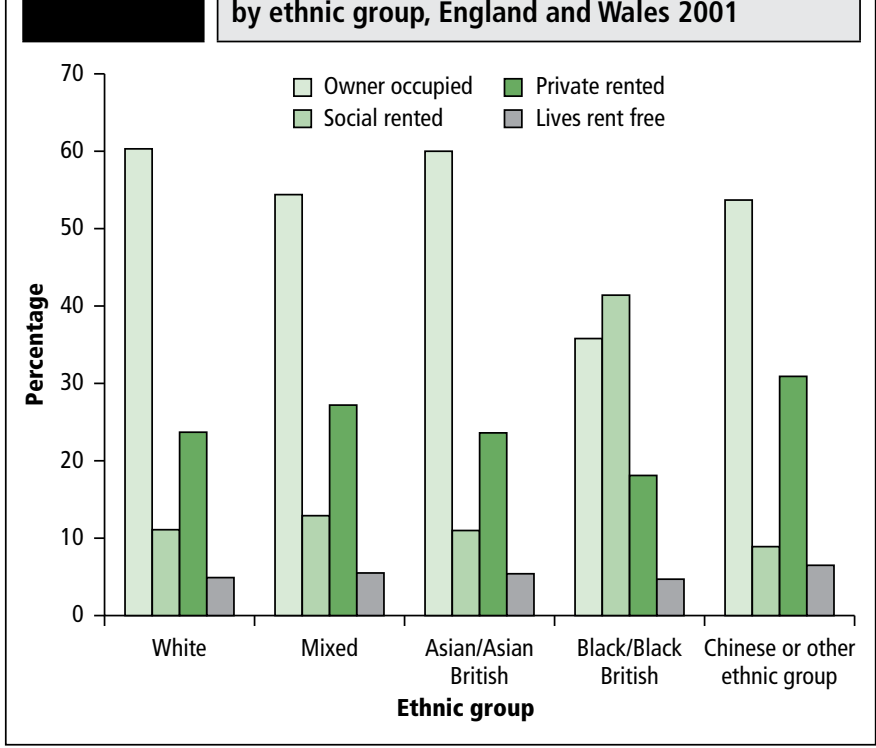

Source: 2001 Census

or 'not good'. Table 8 shows that incoming international migrants to England and Wales display better self-perceived health than the resident population. The younger age distribution of international migrants (Table 2) may lead to an overrepresentation of good health as the latter is inversely related to age. Thus it is important to control for age. Figure 7 therefore compares the proportion reporting 'not good' health among older international migrants and the resident population broken down into 10-year age groups. Self-perceived health deteriorates with age but within all age groups, a lower proportion of international migrants report 'not good' health than the total resident older population. There is nearly a ten percentage point difference in those reporting not good health at ages $90+$ with only 27 per cent of international migrants aged $90+$ reporting 'not good' health compared to 36 per cent of the population in general. This may explain their capacity to migrate internationally at later ages. Better health usually equates to improved mobility and is therefore likely to dictate the motives behind the migration, i.e. a desired rather than a necessary move.

Previous research by Evandrou (2000) ${ }^{22}$ found that that there are significant differences between ethnic minority groups in health status, with those older people from Pakistani and Bangladeshi origin being significantly more likely to report poor health. That research focused on older black and minority elders living in the UK. Table 9 presents data on the health of recent international older migrants by ethnicity. Older migrants from south Asia were least likely to report 'good or fairly good' health (75 per cent) while older international migrants of Chinese or other ethnic origin were most likely to display the best self-perceived health ( 89 per cent). Thus recent international migrants appear to exhibit similar differentials in health to those found in the broader UK ethnic older population.

\section{Table 8} Health of older international migrants by age

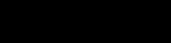

$$
\text { Health of older international migrants by age }
$$

\begin{tabular}{|c|c|c|c|c|c|c|}
\hline \multirow[t]{2}{*}{ Health } & \multicolumn{5}{|c|}{ International migrants to England and Wales aged 60 and over } & \multirow{2}{*}{$\begin{array}{l}\text { All older people aged } 60 \text { and over } \\
\text { resident in England and Wales }\end{array}$} \\
\hline & $60-69$ & $70-79$ & $80-89$ & $90+$ & All ages (60 and over) & \\
\hline Good or fairly good health & $5,810(89.3 \%)$ & $2,177(79.0 \%)$ & $827(76.0 \%)$ & $127(72.6 \%)$ & $8,941(85.0 \%)$ & $8,429,377(77.6 \%)$ \\
\hline Not good health & $697(10.7 \%)$ & $577(21.0 \%)$ & $261(24.0 \%)$ & $48(27.4 \%)$ & $1,583(15.0 \%)$ & $2,428,150(22.4 \%)$ \\
\hline Total & $6,507(100 \%)$ & $2,754(100 \%)$ & $1,088(100 \%)$ & $175(100 \%)$ & $10,524(100 \%)$ & $10,857,527(100 \%)$ \\
\hline
\end{tabular}

Source: 2001 Census 


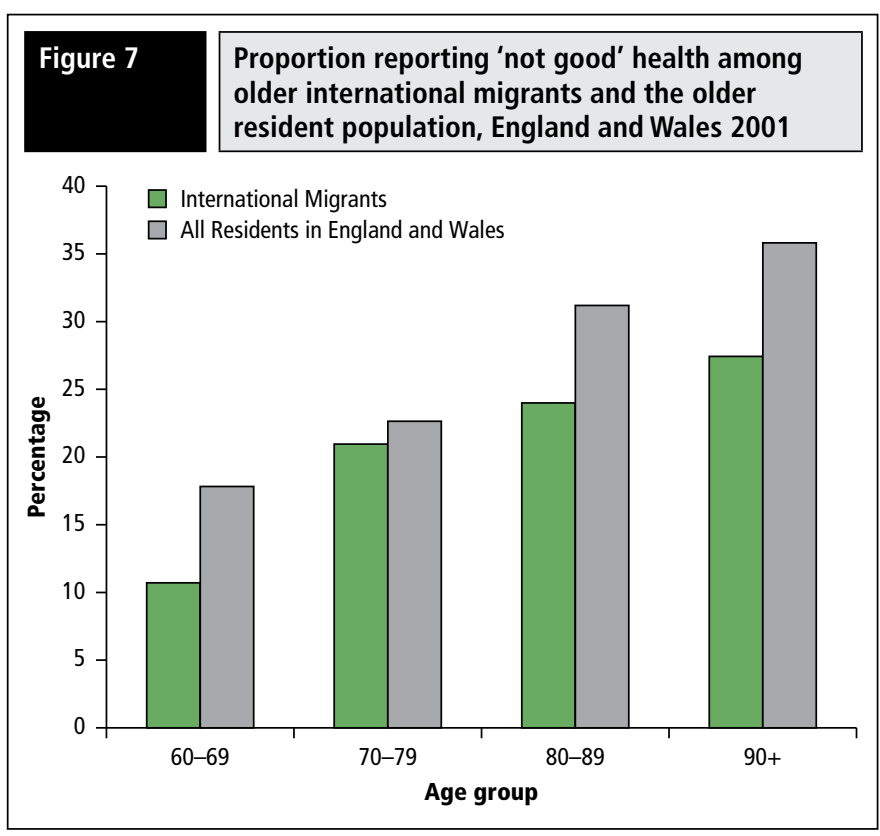

Source: 2001 Census

\section{Summary}

Between 1 April 2000 and 1 April 2001, 10,534 persons aged 60 and over migrated to England and Wales from outside the UK. They were more likely to be younger, male, non-white, not in a couple and healthier than the population as a whole aged 60 and over. The majority came to England and Wales between the ages of 60 and 69, but a high proportion migrated at ages 80 and above.

The analysis has shown that those who migrate internationally in later life exhibit a diverse range of demographic characteristics particularly in terms of their ethnicities and the ages at which they migrate. These characteristics have implications for policy makers and planners, not least for the provision of culturally sensitive and appropriate services. For example, older migrants from South Asia report worse health than the older population in general and these recently arrived migrants may face particular challenges in accessing health services due to language and other cultural barriers. A relatively high percentage of older international migrants lived in private rented accommodation, and this is especially the case for those of Chinese or other ethnic origin. Private rented accommodation may be more insecure than that of other forms of housing, with shorter tenancy agreements. Some housing is also of a poorer quality (Communities and Local Government, 2009). ${ }^{23}$ This has implications in terms of living standards and potential instability in the housing market due to more frequent changes in residence by older international migrants. This is not to say that those who migrate to England and Wales at ages 60 and over will not complete the transition into owner-occupied accommodation at a later stage of the life course.

\section{Key findings}

- Around 1 in 10 people at all ages had moved address in the year prior to the Census in April 2001.

- Among those aged 60 and over, around 0.4 in every 10 changed address in the year prior to the 2001 Census.

- Approximately 0.01 in 10 persons aged 60 and over had moved from an address outside of the UK in the year prior to the 2001 Census.

- The age distribution of older international migrants (60 and over years of age) in 2001 was younger than that of the total population aged 60 and over resident in England and Wales in 2001.

- Older people from White ethnic groups accounted for over three-quarters of international moves to England and Wales.

- Over a fifth of moves were made by non-white older people around half of which were from south Asia and a quarter were Black African or Black Caribbean.

- Fewer older international migrants were married in 2001 (44.8 per cent) than among the older resident population (49.3 per cent).

- Older international migrants were significantly more likely to be re-married (13 per cent) than was the case among the resident population (7.8 per cent).

- Around 37 per cent of Asian older international migrants were widowed in 2001; approximately six per cent more than in any other ethnic group.

- Older international migrants were more likely to live in private rented accommodation at the time of the 2001 Census (23.7 per cent) than all older residents (four per cent).

- Of the older resident population, 73.8 per cent owned property outright in 2001 which compares with 58.5 per cent of older international migrants.

- Over 40 per cent of older international migrants to England and Wales between 2000 and 2001 from Black or Black British ethnic origin lived in social rented accommodation, over three times greater than in any other ethnic group.

- Among older migrants of Chinese or other ethnic origin, almost a third lived in private rented accommodation. This was around seven per cent more than was evident among White older migrants.

- Incoming older international migrants to England and Wales displayed better self-perceived health than the older resident population.

- Among those aged 90 and over, 27 percent of international migrants reported 'not good' health whereas of the population in general, 36 per cent reported this.

- Older migrants from south Asia were least likely to report 'good or fairly good' health (75 per cent) while older international migrants of Chinese or other ethnic origin were most likely to display the best self-perceived health (89 per cent).

\begin{tabular}{|c|c|c|c|c|c|c|}
\hline \multirow[t]{2}{*}{ Health } & \multicolumn{5}{|c|}{ International migrants to England and Wales aged 60 and over } & \multirow{2}{*}{$\begin{array}{l}\text { All older people aged } 60 \text { and over } \\
\text { resident in England and Wales }\end{array}$} \\
\hline & White & Mixed & Asian/Asian British & Black/Black British & $\begin{array}{l}\text { Chinese or other } \\
\text { ethnic group }\end{array}$ & \\
\hline Good or fairly good health & $7,080(86.8 \%)$ & $129(83.2 \%)$ & $890(74.9 \%)$ & $460(78.8 \%)$ & $336(88.9 \%)$ & $8,429,377(77.6 \%)$ \\
\hline Not good health & $1,078(13.2 \%)$ & $26(16.8 \%)$ & $299(25.1 \%)$ & $124(21.2 \%)$ & $42(11.1 \%)$ & $2,428,150(22.4 \%)$ \\
\hline Total (N) & $8,158(100 \%)$ & $155(100 \%)$ & $1,189(100 \%)$ & $584(100 \%)$ & $378(100 \%)$ & $10,857,527(100 \%)$ \\
\hline
\end{tabular}


There is a need for further research into the topic owing to the evident variations in the demographic composition of these migrants by ethnicity. It is likely that 2011 census data will further our understanding of who these migrants are by enabling more in depth and up to date analysis. To understand better the motivations of these incoming migrants and the decision-making process, it would be beneficial to conduct more qualitative focused data collection on incoming international retired migrants to England and Wales.

\section{References}

1 United Nations (2005) World Migrant Stock: The 2005 Revision Population Guide. Available at: $\mathrm{http}: / /$ esa.un.org/migration/p2k0data.asp

2 International Organisation for Migration (2009) 'Global Estimates and Trends.' Available at: www.iom.int/jahia/Jahia/about-migration/ facts-and-figures/global-estimates-and-trends

3 US Census Bureau (2008) World POPClock Projection. Available at: www.census.gov/ipc/www/popclockworld.html

4 United Nations (2006) World Population Prospects: The 2006 Revision. Available at: www.un.org/esa/population/publications/wpp2006/English.pdf

5 Office for National Statistics (2006) Population estimates for UK, England and Wales, Scotland and Northern Ireland. Available at: www.statistics.gov.uk/statbase/Product.asp?vlnk=15106

6 Williams A, King R and Warnes A (1997) 'A Place in the Sun; International Retirement Migration from Northern to Southern Europe' European Urban and Regional Studies 4(2), 115-134.

7 King R, Warnes A and Williams A (1998) 'International Retirement Migration in Europe' International Journal of Population Geography 4, 91-111.

8 Warnes A and Patterson G (1998) 'British Retirees in Malta: Components of the Cross-National Relationship' International Journal of Population Geography 4, 113-133.
9 King R, Warnes A and Williams A (2000) Sunset Lives: British Retirement Migration to the Mediterranean. Oxford International Publishers Limited.

10 Casado-Diaz M, Kaiser C and Warnes A (2004) 'Northern Europeans Retired Residents in Nine Southern European Areas: Characteristics, Motivations and Adjustment' Ageing and Society 24, 353-381.

11 Office for National Statistics (2001) 2001 Census for England and Wales.

12 Rogers A, with Frey W H, Rees P, Speare A and Warnes A (eds.) (1992) Elderly Migration and Population Redistribution. Belhaven, London.

13 Ackers L and Dwyer P (2002) Senior Citizenship? Retirement, migration and welfare in the European Union. Bristol: The Policy Press.

14 Home Office, UK Borders (2008) 'Retired People'. London: Home Office. Available at: www.ukba.homeoffice.gov.uk/ukresidency/eligibility/retiredpeople/

15 Office for National Statistics (2008) Population: Migration. Available at: www.statistics.gov.uk/CCI/nugget.asp?id $=260$

16 Office for National Statistics (2008) International Passenger Survey.

17 Castles S and Miller M (2003) The Age of Migration. Third Edition. Palgrave Macmillan, London.

18 Office for National Statistics (2008) Health: Life Expectancy. Available at: www.statistics.gov.uk/cci/nugget.asp?ID $=168$

19 Warnes A and Rees P (1986) 'Elderly Migrants in Great Britain'. Paper Presented at the Colorado International Conference on Elderly Migration.

20 Speare A and Goldscheider F (1987) 'The Effects of Marital Status Change on Residential Mobility' Journal of Marriage and the Family 49(2), 455-464.

21 Bures R M (1997) 'Migration and the Life Course: Is there a Retirement Transition?' International Journal of Population Geography 3, 109-119.

22 Evandrou M (2000) 'Ethnic inequalities in health in later life' Health Statistics Quarterly No. 8, Winter 2000, pp. 20-28.

23 Department for Communities and Local Government (DCLG) (2009) English House Condition Survey 2007 Headline Report. Available at: www.communities.gov.uk/documents/statistics/pdf/1133548.pdf 